\title{
Paideusis
}

\section{Valuing Administration: The Role of Philosophy in Educational Administration}

\section{Sharon Bailin and Jon Young}

Volume 4, Number 1, 1990

URI: https://id.erudit.org/iderudit/1073394ar

DOI: https://doi.org/10.7202/1073394ar

See table of contents

Publisher(s)

Canadian Philosophy of Education Society

ISSN

0838-4517 (print)

1916-0348 (digital)

Explore this journal

Cite this article

Bailin, S. \& Young, J. (1990). Valuing Administration: The Role of Philosophy in Educational Administration. Paideusis, 4(1), 39-44.

https://doi.org/10.7202/1073394ar

This document is protected by copyright law. Use of the services of Erudit (including reproduction) is subject to its terms and conditions, which can be viewed online.

https://apropos.erudit.org/en/users/policy-on-use/ 


\title{
Valuing Administration: The Role of Philosophy in Educational Administration
}

\author{
Sharon Bailin and Jon Young \\ University of Manitoba
}

\section{Philosophy}

Dans cet essai, nous allons essayer de justifier la philosophie de l'éducation pour ce qui trait à la formation des éducateurs en général et la formation des administrateurs en particular.

Dans cette premiere partie, nous essayons de démontrer les problèmes rattachés à la justification tout a fait pratique et à la justification tout a fait théorique. Nous soutenons que la philosophie a du mérite parce qu'elle encourage la réflexion sur la pratique. Elle met en cause les présuppositions et les valeurs qui sont a la base de la pratique et ajoute une perspective épistemologique a l'appreciation de la recherche.

Departments of foundations in Canadian faculties of education are currently faced with the problem of justifying their existence in the face of an increasingly technical orientation towards education. In a context where the preparation of teachers and administrators is viewed in terms of training in the practical know-how which is the product of experienced practice and the passing on of information amassed through empirical research, the role of philosophy becomes increasingly imperilled. An important question, then, for philosophers of education is how to justify the inclusion of the study of philosophy in the preparation of teachers and administrators.

There are a number of possible avenues of justification. One is to yield to the programmatic orientation and to attempt to justify philosophy in terms of its immediate usefulness. One example might be a course in ethics and administration justified in terms of helping the administrator to become more efficient in making the inevitable ethical decisions which arise. But we would argue that this is an inappropriate avenue of justification because philosophy will not yield immediate and uncontroversial answers to practical problems. Philosophical reflection requires some distance from practice. ${ }^{1}$ And engaging in philosophical speculation may, in fact, render one less efficient, at least temporarily, in that actions which may have been unquestioned previously become problematic and then the path to "right action" may become unclear or ambiguous. Moreover, there is a danger in philosophy being undertaken in the service of immediate practice and that is that the philosophical enterprise may be domesticated. Philosophy involves examining values and questioning assumptions, but in being geared to efficient practice, it may lose its critical leverage over practice.

Another possible avenue of justification lies in ignoring the calls for practical relevance and viewing the role of philosophy in terms of its more general educative function. Educators should themselves be educated persons and philosophy constitutes an important part of the intellectual heritage of such persons if we view human beings as inquirers who seek to understand and to make meaning, then philosophy can be seen as chronicling such inquiry. And if one of the roles of the educator is to promote inquiry, then philosophy is an appropriate grounding. 
There is certainly some cogency to this sort of justification, but it is far from adequate. For one thing, it would only justify the inclusion of "some sort" of philosophy course in teacher and administrator education, a requirement that could be met by an Arts course, but would provide no justification for philosophy in education in particular. But there is an important role for philosophy of education. It informs practice in an important way. Indeed, if the students in philosophy of education courses became better educated in some general sense but never went on to raise philosophical questions about their teaching or administering, would those causes be considered successful?

There is an avenue of justification which lies between the two already suggested. If we take Aristotle's categories of knowledge, then philosophy of education would fall neither in the category of productive knowledge, which is purely instrumental, nor in the category of theoretical knowledge, which is separate from practice. Rather, it would be a species of practical knowledge, knowledge which has a theoretical component but which informs practice. Education practice rests on assumptions about values and about aims of education. It is elucidated in terms of concepts, and justified through arguments. Philosophy can clarify concepts, uncover and scrutinize assumptions, and examine the cogency of arguments. And in unmasking the values and assumptions hidden behind authoritative-sounding pronouncements, philosophy can counter the tendency to view educational practice as simply a question of the application of technique, showing that questions can be raised not only about means to ends, but about ends themselves. One might view as one goal of philosophy of education to arrive at better justified practice, and the search for justification may well lead to new and different practices. Thus, the effects of philosophy of education on practice can be real and palpable.

The notion of justification points to a related role that philosophy can play for the preparation of educators in general, and administrators in particular. The results of research as well as handed-down experience are utilized in the education of teachers and administrators to provide prescriptions for practice. In addition, at the graduate level, these individuals are themselves engaged in research. 2 Thus, it is crucial that they understand and are able to evaluate such research. An examination of the nature and justification of knowledge claims is a central concern of epistemology. Thus, one could argue that a grounding in epistemology, an exploration of concepts such as truth, justification, evidence, objectivity, relativism, and inquiry should be a part of the education of educators.

\section{Administration}

Maintenant nous allons traiter, en bref, l'évolution de la pensée en administration scolaire depuis les années 1945. Nous allons développer une critique du modèle dominant de l'administration et décrire un modèle l'accent sur les valeurs. La philosophie joue un rôle important dans ce modèle.

So far two basic justifications for the study of philosophy in faculties of education have been advanced. Both apply directly to any attempt by universities to prepare students for the challenges of administrative practice. The first of these arguments would maintain that administrative behaviour is never reducible simply to matters of technique but rather always poses questions of human values - whether these are made explicit or not - and that administrators 
should be prepared to engage these questions with care and responsibility. The second argument asserts that the study of administrative behaviour and our attempts to use these studies to offer solutions to problems in education requires that we understand the knowledge claims that underpin our research and the solutions that we construct from them. As Gabriela Lakomski notes:

No matter what methods we use to research and attempt to solve problems in education and educational administration, we want our findings to be based on more than our own opinions or preference. We want them to be knowledge. But in order to create knowledge rather than mere belief, we have to have an adequate theory of knowledge which helps us sort one from the other. In order to do this well, we have to be able to justify what we find in as coherent a manner as possible, without having to presume more in the epistemology we adopt as researchers than it can actually deliver. ${ }^{3}$

While these arguments may not be problematic to philosophers, they have been somewhat problematic amongst those who study and practice in the worlds of educational administration, and, in large part, remain so today. ${ }^{4}$ It is, therefore, necessary to give some brief attention to the history of administrative thought in North American education in the second half of this century.

The late 1940s and the 1950s witnessed what Kelsey and Long have referred to as an "emergent orthodoxy" in the study of educational administration. 5 A pre-war concern with practical principles of organization and managerial techniques derived from the experiences and reflections of administrators, rather than scientists, was summarily discarded in favour of a more theoretical orientation. That orientation specifically demanded that the study and practice of educational administration be driven by empirical research grounded in social science theory.

The intellectual roots of this orthodoxy are to be found in Herbert Simon's seminal work Administrative Behaviour (1945) which, Greenfield suggests, offered, "a totally new conception of the nature of administration and, more importantly, a new set of rules for inquiring into administrative realities".6 Organizations such as the National Conference of Professors of Educational Administration (NCPEA) founded in 1947 and the influential University Council of Educational Administration (UCEA) founded in 1956 brought educational administrators and social scientists together. They provided the network for the new "theory movement" which rapidly came to dominate the study of administration and the definition of appropriate preparation for aspiring administrators in educational settings in North America. In the 1960s and 1970s, this influence expanded into Britain and Australia through organizations such as the Commonwealth Council for Educational Administration.

So successful was this movement that by 1970 Daniel Griffiths, one of the most influential spokespersons for the "theory movement," could proclaim:

While certainly, no group has felt recently that enough was known, there was a belief that educational administration was on the right track. Most, if not all, dissertations employed theoretical concepts and structures, textbooks contained descriptions of several theories, and administrators were taught to make theoretical analyses. In Kuhn's language, there was an accepted paradigm, and the processes of "normal science" were ongoing."

What is important here, at least for critics of the movement, is not that it sought to be "theoretical" or "scientific," but that it proceeded upon an exces- 
sively narrow and misguided view of what constituted theory and science. It was, in essence, a science of administration grounded exclusively in positivistic inquiry and in the claimed objective view of the social world that could offer its followers a rational basis for decision making and a value-free technology for increasing the effectiveness and efficiency of organizations. Greenfield, perhaps the most persistent and articulate critic of this orthodoxy, notes:

The force of the assumptions of this method of inquiry dispenses with any knowledge not based upon objective and empirical observation. Such inquiry must therefore deny the world of value. It must abjure as proper subjects for study all of what Halpin ... called "Social Philosophy" and all questions pertaining to "right human conduct". 8

Such a view, promulgated through university faculties, has significantly informed administrative practice. Greenfield continues:

The horror of ...[this] neutered science appears only with the realization that it conforms, almost perfectly, to the view that administrators seem to want to have of themselves: that they are instruments of an objective, selfless rationality. Administrative science ... has done much to establish the belief that devalued, but rational, decision making is desirable, attainable, and scientifically verifiable. The belief relieves the anxiety of decision making and removes the administrator's sense of responsibility for his decisions. ${ }^{9}$

Such a vision of educational administration has little place for philosophers. However, since the mid-1970s this orthodoxy has at least had its challenges, and as a result the field of educational administration has more recently been described variously as "fragmented" 10 and as a "heterodoxy". 11 While the theory movement may be alive and largely unrepentant in much current writing in educational administration, there is an increasing attention being given to a broader view of theory and science and the methods of scientific inquiry - much of it originating outside of the United States - that recognizes the sciences of administration as a science of value. Philosophers of education have played a central role in this reconceptualization of the study and practice of administration as a primarily moral and political activity rather than a technical one. 12

If administration is conceived this way, it means that those who study administration must be prepared to adopt new ways to inquire into the place of values in human actions and the place of power and its relation to values. And, if we are to presume to teach administrative theory to people who will exert power over others in the name of administration, we must require them, too, to reflect on such complexities. For those who will do this in schools, there is a particular urgency. As Holmes notes:

All administration is centrally concerned with values. Educational administration is doubly involved with values because education, as opposed to, say, tree farming, is continually fraught with moral choices. ${ }^{13}$

Those of us attracted to this vision of administration are likely to find more interesting company among philosophers, sociologists, historians and anthropologists and to be more welcome in departments of foundations than amongst traditional departments of educational administration that still lay claim to the painless techniques of administrative science. 


\section{Conclusion}

What all this suggests is not merely the appending of philosophical issues to the study of administration, nor the conversion of philosophy into a service activity for administration, but, rather that it involves a reconceptualization and re-valuing of educational administration. Christopher Lasch has stated this position most forcefully:

Moral values cannot be added to technical projects as an afterthought, as if medicine, say, which has turned its back on the humble art of healing in order to undertake the technological conquest of disease, could recover its ethical mission at the last minute by debating the pros and cons of pulling the plug. The proper role of humanists is not to bring "human values" to the attention of technicians otherwise engaged in a purely instrumental approach to their calling, but to demand the restoration of the practical or moral element in callings that have degenerated into techniques - to insist, in other words, that moral considerations represent the very essence of practical activity, not another special area of expertise the claims of which have to be balanced against those of other specialities. ${ }^{14}$ 


\section{Notes}

${ }^{1}$ These categories of knowledge are laid out in Aristotle's Nicomachean Ethics Book VI.

${ }^{2}$ See R. MacPherson (ed.), Ways and Meanings of Research in Educational Administration (Armidale: University of New South Wales, 1986).

${ }^{3}$ See G. Lakomski, "The Cultural Perspective in Educational Administration," in R. MacPherson (ed.), Ways and Meanings of Research in Educational Administration (Armidale: University of New South Wales, 1986), 116.

${ }^{4}$ That educational administration, particularly in the United States, continues to be driven by a technical orientation rather than a philosophical orientation is well illustrated in the recent commission report on the preparation of school administrators by D. Griffiths, R. Stout, and P. Forsyth entitled Leaders for America's Schools: The Report and Papers of the National Commission on Excellence in Educational Administration (Berkeley: McCutchan, 1988).

${ }^{5}$ See J. Kelsey and J. Long, "Educational Administration: Orthodoxy and Heterodoxy," in R. Lawson and R. Schnell (eds.), Educational Studies: Foundations of Policy (Washington: University Press, 1983), 407-447.

${ }^{6} \mathrm{~T}$. Greenfield, "The Decline and Fall of Science in Educational Administration," Interchange, 17(2), 1986, 57.

${ }^{7} \mathrm{D}$. Griffiths, "The Individual in Organizations: A Theoretical Perspective," Educational Administration Quarterly, 13(2), 1970, 1.

${ }^{8}$ Greenfield, op. cit., 60.

${ }^{9}$ Ibid., 62.

${ }^{10} \mathrm{D}$. Willower, "Inquiry into Educational Administration: The Last 25 Years and the Next," Journal of Educational Administration, 25(1), 1987, 12-28.

${ }^{11} \mathrm{~J}$. Kelsey and J. Long, op. cit.

${ }^{12}$ See, for example, C. Hodgkinson, The Philosophy of Leadership (Oxford: Blackwell, 1983); C. Evers, "Educational Administration and the New Philosophy of Science," Journal of Educational Administration, 26(1), 5-22; and G. Lakomski, op. cit.

${ }^{13}$ M. Holmes, "Comments," Interchange, 17(2), 1986, 84.

${ }^{14}$ C. Lasch, "“Excellence' in Education," Issues in Education, 3(1), 1985, 11. 